\title{
SDG's Quality Education Approach: Comparative Analysis of Natural Sciences Curriculum Guidelines between Taiwan and Colombia
}

\author{
José Molina ${ }^{1, *,+}$, Nguyen Viet Hai ${ }^{2}$, Ping-Han Cheng ${ }^{3}$ iD and Chun-Yen Chang ${ }^{3, *(D)}$ \\ 1 Facultad de Ciencias de la Educación, Universidad Pedagógica y Tecnológica de Colombia, \\ Tunja 150003, Colombia \\ 2 Graduate Institute of Science Education, National Taiwan Normal University, Taipei 10091, Taiwan; \\ 60845030s@ntnu.edu.tw \\ 3 Science Education Center, National Taiwan Normal University, Taipei 10091, Taiwan; phcheng@ntnu.edu.tw \\ * Correspondence: jose.molina05@uptc.edu.co (J.M.); changcy@ntnu.edu.tw (C.-Y.C.); \\ Tel.: +57-3125540841 (J.M.); +886-2-7734-6751 (C.-Y.C.) \\ + Visiting Scholar Taiwan Fellowship 2020.
}

check for

updates

Citation: Molina, J.; Hai, N.V.; Cheng, P.-H.; Chang, C.-Y. SDG's Quality Education Approach: Comparative Analysis of Natural Sciences Curriculum Guidelines between Taiwan and Colombia. Sustainability 2021, 13, 3352. https://doi.org/10.3390/su13063352

Academic Editors: Teen-Hang Meen and Ralph Hansmann

Received: 1 February 2021

Accepted: 17 February 2021

Published: 18 March 2021

Publisher's Note: MDPI stays neutral with regard to jurisdictional claims in published maps and institutional affiliations.

Copyright: (c) 2021 by the authors. Licensee MDPI, Basel, Switzerland. This article is an open access article distributed under the terms and conditions of the Creative Commons Attribution (CC BY) license (https:// creativecommons.org/licenses/by/ $4.0 /)$.

\begin{abstract}
In this comparative analysis, the cases of Taiwan and Colombia display two paths for designing a natural sciences curriculum related to quality education goals. Their differences are based on their central concepts, definitions of learning stages, delimitations of cross-subjects and cores of scientific knowledge, and alignment with international assessments. The core practices in Taiwanese curriculum guidelines are to develop inquiries, research, and experimentations to promote scientific literacy and citizenship. In contrast, the core Colombian practices construct explanations based on scientific ideas, gathering information, and using evidence. Between both countries, there is also a concordance over practices related to obtaining and communicating information. These results show the importance of curriculum policy factors such as epistemological definitions, diagnostics and representations of social expectations, alignment instruments, curriculum definitions, and design criteria of teaching processes. The differences between national curriculum policies are identified in a comparative strategy of contexts, medium-term processes to reform the national education systems or schooling features. Curriculum guidelines respond to their intellectual traditions, theoretical and pedagogical influences, and current requirements of policies. These criteria allow for the identification of cooperative issues in specific areas of science education between both countries, such as teacher education, technological and pedagogical knowledge, and curriculum alignment.
\end{abstract}

Keywords: curriculum alignment; curriculum guidelines; students' performance; international comparison

\section{Introduction}

\subsection{Context of the Comparative Analysis}

According to the Sustainable Development Goal of quality education, the implementation of education policies and learning processes demands a set of characteristics to achieve conditions to "ensure inclusive and equitable quality education and promote lifelong learning opportunities for all." The target number 4.7 from the quality education goal refers to a fundamental and substantial relationship between knowledge and political, normative, cultural, and economic aspects in contemporary society. The quality education goal also demands that each national education system implement policies to develop lifelong learning through multiple pathways. In this context, the practices required to construct student's proficiency and appreciation for science at school [1] and the types of knowledge to develop scientific literacy are crucial aspects for designing, implementing, and evaluating curriculum policies in different countries [2].

The links between the Sustainable Development Goals, the main factors that belong to the quality education goal and public education policies, are (i) national education 
policies, (ii) curricula, (iii) teacher education, and (iv) student assessments. In this context, our purpose was to study how these factors are present in national education systems from Taiwan and Colombia. For this inquiry, we considered two comparability criteria: (a) that both countries participate in the Organization for Economic Cooperation and Development (OECD) and regularly participate in the Program for International Student Assessment (PISA), and (b) that the study be initial and exploratory; therefore, the natural sciences domain was defined as the main structure of knowledge [3]. According to these criteria, a few conditions could be met to compare these national cases: (i) identification of focus content (categories, topics, contents, cognitive demands, abilities, and skills to solve problems), (ii) expectations about students' performance, (iii) rationales related to values such as equity and inclusion, (iv) pedagogical aspects, and (v) requirements and suggestions connected to processes of curriculum implementation [4].

This set of criteria is observed in the official documents where the public policy of education is expressed as "cognitive interest" and curriculum guidelines [5]. However, these criteria also require a major grade of specifications to know by what means the goals of curriculum policies define which sets of knowledge should be considered to develop goals, competencies, and social inclusion [6]. In the same sense, the analysis of curriculum goals contributes to guiding educational research about teachers' practices, training [7], and pedagogical change inspired by their relationship with scientific approaches to technology education and teaching [8,9]. From the perspective of assessing students' performance, "content knowledge" must be incorporated as a critical factor to articulate scientific knowledge, citizenship, and learning experience, which can be developed through the science education field.

Therefore, our main purpose was to analyze Colombian and Taiwanese curriculum guidelines and describe their characteristics from the Sustainable Development Goals' curriculum perspective. Thus, our aims were:

$\bigcirc$ To delimit the analysis framework on the practice and performance components in natural sciences in the curriculum guidelines;

To analyze the practice and performance components in natural sciences in the curriculum guidelines in Colombia and Taiwan;

- To compare the practice and performance components in natural sciences in the curriculum guidelines in Colombia and Taiwan; and

$\bigcirc \quad$ To describe the practices and performance in the curriculum oriented towards development in Colombia and Taiwan.

\subsection{Delimitation Criteria}

\subsubsection{Proficiency in Science and Scientific and Engineering Practices}

Science is a system of ideas [10] and practices [11]. Researchers have suggested that to achieve proficiency in science learning, one needs to pull together four learning practice strands. Firstly, one needs to know, use, and interpret scientific explanations about the surrounding world. The second concept is to know how to build up scientific ideas by generating and evaluating scientific evidence and explanations. The third strand is understanding the scientific community's social aspect, which involves the nature, discourse, and development of a particular scientific theory. Finally, one needs to engage in scientific practices actively. Therefore, to start constructing science proficiency, it is necessary to provide students with opportunities to participate in various scientific activities.

However, science learning, like other learnings, should be considered a combination of knowledge and practice [12]. Therefore, rote learning activities or rote following of scientific procedures without understanding the principle would not be meaningful participation in science learning. After significant shifts from rote learning, science education has focused more on the process of building scientific knowledge [13]. The framework of K-12 science education suggests a list of eight Scientific and Engineering Practices (SEPs), which are the methods that scientists and engineers use to do science [14]. This list of practices would be 
used, combined with interdisciplinary core ideas and crosscutting concepts, to establish students' learning performance and guide science learning [15].

The eight scientific and engineering practices are (p. 42) asking questions and defining problems, developing and using models, planning and carrying out investigations, analyzing and interpreting data, using mathematics and computational thinking, constructing explanations and designing solutions, engaging in argument from evidence, and obtaining, evaluating, and communicating information.

Different studies have used science and engineering practices to analyze curricula [16] and brought up some interesting views about the distribution of each SEP, the complexity across grades, and the clarity of learning performance in the national curriculum. Therefore, we used the SEPs as the main component of our coding framework.

\subsubsection{Scientific Literacy and Levels of Proficiency}

Another pathway for students to develop lifelong science learning is to build up scientific literacy. The notion of scientific literacy has been discussed for a long time and many different but related definitions have been come up with [17,18]. In 2015 and 2018, the OECD redefined this notion by reflecting the latest discussions about scientific literacy and provided the definitions as follows: Scientific literacy is the ability to engage with science-related issues and with the ideas of science as a reflective citizen. Therefore, a scientifically literate person is willing to engage in reasoned discourse about science and technology [19] (p. 100).

Scientific literacy consists of three scientific competencies: (a) explaining phenomena scientifically, (b) evaluating and designing scientific inquiry, and (c) interpreting data and evidence scientifically. These are some of the core features of the PISA test. Competencies also require scientific knowledge types: content, procedural, and epistemic. The PISA science framework includes the depth of knowledge level that identifies both cognitive demand and the expected depth level of knowledge to make it assessable.

Based on the theory of how competencies develop, a reporting scale describing students' ability with respective levels was established [20]. The reporting scale consists of seven levels, from Level $1 \mathrm{~b}$ to Level 6, and represents students' abilities, ranging from basic to complex, respectively. This scale served as the guide on which later PISA experts would build test items [21]. Many studies have utilized the PISA framework to analyze curricula [22], but no study has attempted to use the reporting scale. However, we used the scale as a supplement and triangulated means to the main SEP framework.

\subsubsection{Description of Students' Practice in Colombian Curriculum Guidelines in Natural} Sciences, Grades 6-7 and 8-9

According to article $5^{\circ}$ of Law 115 from 1994, compulsory education considers protecting the environment, ecology, and preservation of natural resources as a common goal in all national education system levels. In addition, natural sciences and environmental education are critical and fundamental areas of knowledge that must be offered by each school's Institutional Educational Project. This constitutional mandate is followed by the document Lineamientos Curriculares Ciencias Naturales y Educación Ambiental, where conceptual, pedagogical, and didactic references are presented to design the school curriculum. The main areas of these guidelines are (i) philosophical and epistemological referents; (ii) sociological referents related to the school as an institution of knowledge and values; (iii) psychocognitive referents as scientific thought, processes of thinking and action, and creativity and problem-solving; and (iv) pedagogical implications, such as (a) the didactic and teacher role, (b) the scientific language and teaching of natural sciences and environmental education, (c) the role of the laboratory, and (d) assessment [23].

In addition to these documents, the students' performance is defined in the document Estándares Básicos de Competencias, which offers a guide to curriculum design, syllabi, content-based planning, school projects, and classroom practices. Additionally, these guidelines aim to orient the elaboration of school books, materials, assessments, and teacher training [24]. The standards organize the learning process by grouping "grades" to 
develop the competencies' "increasing levels of complexity." "Competence" is defined as a flexible ability that could be uploaded in different contexts as new situations. These contexts do not have a direct connection with situations where learning is acquired. Therefore, competence implies understanding the meaning of each activity and its ethical, social, economic, and political aspects. The standards aim to provide a horizontal reading to develop methodologies and learning processes promoting students' approaches to scientific knowledge and scientific procedures, achieving the development of personal commitment and awareness. The standards also offer a vertical reading to represent the complexity levels of approaching to scientific procedures, scientific concepts, and responsibilities.

The relationship between Lineamientos Curriculares and Estándares Básicos de Competencias is proposed in Table 1:

Table 1. Relationship between Colombian curriculum guidelines.

\begin{tabular}{|c|c|c|}
\hline Curriculum Guidelines & General Criteria from Basic Standards & Core Idea of Standards \\
\hline $\begin{array}{l}\text { Processes of thinking and action } \\
\text { related to basic scientific research }\end{array}$ & $\begin{array}{l}\text { Questioning and problems } \\
\text { Search and inquiry processes } \\
\text { Formulation of hypotheses } \\
\text { Explanation of theories } \\
\text { Analysis and synthesis to understand the } \\
\text { usefulness of what has been learned }\end{array}$ & $\begin{array}{l}\text { Students approach knowledge as a } \\
\text { natural scientist. }\end{array}$ \\
\hline $\begin{array}{l}\text { Basic scientific knowledge about } \\
\text { biological, physical, and } \\
\text { chemical relations }\end{array}$ & $\begin{array}{l}\text { Using disciplinary knowledge } \\
\text { Cross-disciplinary articulation } \\
\text { Inquiry of complementarity } \\
\text { Components of core idea: living } \\
\text { environment, physical environment, science } \\
\text { technology, and society }\end{array}$ & $\begin{array}{l}\text { Students handle knowledge of } \\
\text { natural sciences. }\end{array}$ \\
\hline Values and responsibilities & $\begin{array}{l}\text { Knowing and critical appraisal of discovery } \\
\text { and advances in science } \\
\text { Ethical awareness training } \\
\text { Evaluating the role of the sciences in relation } \\
\text { to the environment and quality of life } \\
\text { Occupational training }\end{array}$ & $\begin{array}{l}\text { Development of personal and } \\
\text { social commitments. }\end{array}$ \\
\hline
\end{tabular}

Regarding the organization of the implementation of these curriculum criteria, Colombian curriculum guidelines consider specific standards and standard core ideas that generate different actions of thinking and production, which are composed of 154 indicators of abilities, skills, and expectations of students' performance. This specific curriculum structure is presented in the Table 2:

Table 2. Main characteristics of Colombian curriculum guidelines.

\begin{tabular}{cll}
\hline Grades & \multicolumn{1}{c}{ Standards } & \multicolumn{1}{c}{ General Description of "Actions of Thinking and Production" } \\
\hline & $\begin{array}{l}\text { Students identify conditions of change } \\
\text { and equilibrium in living beings and } \\
\text { ecosystems. }\end{array}$ & $\begin{array}{l}\text { These actions are related to analysis through asking and formulate specific } \\
\text { questions based on observations, register, previous arguments and data } \\
\text { collection, and communication into a basic experimental framework. }\end{array}$ \\
$\begin{array}{l}\text { Students establish relationships between } \\
\text { the macroscopic and microscopic } \\
\text { characteristics of matter and the physical } \\
\text { and chemical properties of the substances } \\
\text { that constitute them. }\end{array}$ & $\begin{array}{l}\text { These actions are based on (a) understanding properties and structure of } \\
\text { matter; (b) describing and explaining elements, models, and relationships } \\
\text { between elements and chemical and physic processes; (c) verifying and } \\
\text { classifying characteristics of living beings, organisms, systems, and } \\
\text { ecosystems; and (d) identifying, recognizing, and analyzing relationships } \\
\text { resources, the way they have been used in } \\
\text { technological developments, and the } \\
\text { consequences of human action on them. }\end{array}$ & $\begin{array}{l}\text { between environment, health, and scientific knowledge applied to some } \\
\text { social practices. } \\
\text { These students' actions lead them to (a) understand and evaluate scientific } \\
\text { knowledge and practices as a support to be respectful with themselves, the } \\
\text { environment, and social interactional patterns, and (b) apply characteristics } \\
\text { of scientist work to establish relationships with their classmates, study } \\
\text { teams, and schools. }\end{array}$ \\
\hline
\end{tabular}


Table 2. Cont.

\begin{tabular}{|c|c|c|}
\hline Grades & Standards & General Description of "Actions of Thinking and Production" \\
\hline $8-9$ & $\begin{array}{l}\text { Students explain the variability in } \\
\text { populations and biological diversity due } \\
\text { to reproduction strategies, genetic } \\
\text { changes, and natural selection. } \\
\text { Students explain change and } \\
\text { conservation conditions in the various } \\
\text { systems considering the transfer and } \\
\text { transport of energy and its interaction } \\
\text { with matter. } \\
\text { Students identify applications of some } \\
\text { knowledge about inheritance and } \\
\text { reproduction to improve the quality of } \\
\text { life of populations. } \\
\text { Students identify commercial and } \\
\text { industrial applications of energy } \\
\text { transport and matter interaction. }\end{array}$ & $\begin{array}{l}\text { These actions are related to observing, registering, collecting data, applying } \\
\text { scientific theories, explaining while oriented by a basic hypothesis, using } \\
\text { mathematics procedures, and communicating conclusions into a basic } \\
\text { experimental framework. Theses actions also consider different applications } \\
\text { through mathematical resources, evaluating the quality of collected } \\
\text { information, modeling to predict, and measuring with suitable instruments. } \\
\text { These actions are based on (a) understanding topics of inheritance material, } \\
\text { comparing reproduction systems, and relating birth rate and populations, } \\
\text { taxonomies, species, and living beings, as well as theories about species and } \\
\text { their reproduction; (b) comparing characteristics of materials, recognizing } \\
\text { forms of energy, electrostatic forces, and mechanical waves, and } \\
\text { differentiating models for explaining nature and behavior of light; and (c) } \\
\text { identifying the usefulness of DNA and genetic biodiversity, and different } \\
\text { applications of scientific knowledge in industries, instruments, } \\
\text { communications, pollution, human reproduction, and health. } \\
\text { Commitments are made (a) to develop a respectful attitude towards the } \\
\text { environment, different points of view, and a collaborative disposition to use } \\
\text { scientific knowledge; and (b) to use scientific knowledge as a crucial } \\
\text { resource to make decisions about health, oneself and one's own body, } \\
\text { gender equity, reproduction, sexuality, and cultural patterns. }\end{array}$ \\
\hline
\end{tabular}

1.2.4. Description of Students' Practice in Taiwanese Curriculum Guidelines in Natural Sciences, Grades 7-9

In the Curriculum Guidelines of 12-year Basic Education, in natural sciences, one of the main concepts is "science competency," which is related to the development of citizens who can incorporate scientific knowledge into daily activities, judgments, and relationships with the environment. The purpose is to reach value-driven curriculum implementation, such as rational attitude, innovative thinking, judgments, and actions supported by scientific knowledge. This type of citizenship requires students to deploy learning based on an active exploration, experimental operation, and multiple learning. The core of scientific knowledge is defined by scientific inquiry, practices, and argumentation, as well as seven cross-subjects defined as material and energy, structure and function, system, and scale, change and stability, interaction, science and daily life, resources, and sustainability [25].

In addition, curriculum goals in natural sciences are articulated with a learning stage and specific learning performance framework. The junior high school stage corresponds to the fourth learning stage, which moves from "concrete operation to abstract thinking" through practices such as asking questions, forming hypotheses, designing simple experiments, collecting data, drawing charts and tables, and presenting evidence and conclusions. Scientific inquiry is the main reference for identifying problems, analysis, assessment, planning, multiple learning, and operating technology incorporating useful information into problem-solving practices. The junior high school stage has a framework of learning performance organized in Table 3.

Table 3. Main characteristics of Taiwanese curriculum guidelines.

\begin{tabular}{cll}
\hline Items & \multicolumn{1}{c}{ Sub-Items } & \multicolumn{1}{c}{$\begin{array}{c}\text { General Description of the Learning } \\
\text { Performance of the Fourth Stage }\end{array}$} \\
\hline $\begin{array}{c}\text { Inquiry ability } \\
\text { Thinking ability }\end{array}$ & $\begin{array}{l}\text { Imagination and creativity } \\
\text { Reasoning and argumentation } \\
\text { Critical thinking }\end{array}$ & $\begin{array}{l}\text { Students can connect them with observing phenomena and } \\
\text { collected data after acquiring knowledge and concepts of } \\
\text { natural sciences. From imagination promoted by } \\
\text { observation, students can categorize and model through } \\
\text { experimentation and collaborative work. Students' } \\
\text { performance is developed through guided activities to } \\
\text { evaluating models and apply scientific understanding in } \\
\text { daily life. }\end{array}$ \\
\hline
\end{tabular}


Table 3. Cont.

\begin{tabular}{cll} 
Items & \multicolumn{1}{c}{ Sub-Items } & $\begin{array}{c}\text { } \\
\text { General Description of the Learning } \\
\text { Performance of the Fourth Stage }\end{array}$ \\
\hline $\begin{array}{c}\text { Inquiry ability } \\
\text { problem-solving }\end{array}$ & $\begin{array}{l}\text { Observing and identifying } \\
\text { Planning and executing } \\
\text { Analyzing and finding } \\
\text { Discussing and communicating }\end{array}$ & $\begin{array}{l}\text { Scientific reasoning and reliable investigations are the basis } \\
\text { for analyzing and generalizing and applying scientific and } \\
\text { mathematical knowledge. Planned observation and } \\
\text { problem recognition are core activites in scientific practices. } \\
\text { Students' performance is developed through activities } \\
\text { under guidance, utilizing qualitative observations and } \\
\text { measurements. }\end{array}$ \\
Attitude towards & $\begin{array}{l}\text { Cultivate an interest in scientific inquiry } \\
\text { Develop the habit of applying scientific } \\
\text { thinking and inquiry } \\
\text { of science }\end{array}$ & $\begin{array}{l}\text { Students' performance is related to achieving a sense of } \\
\text { accomplishment through hands-on experimentation. } \\
\text { Additionally, sharing experiences allow them to evaluate } \\
\text { scientific knowledge and incorporate it into their decisions. } \\
\text { Three aspects are part of this experience: the legitimacy of } \\
\text { scientific knowledge, the influence and appraisal of the } \\
\text { scientific research context, and the perception of scientific } \\
\text { practices' values. }\end{array}$ \\
\hline
\end{tabular}

\section{Materials and Methods}

\subsection{General Background}

This research considered two criteria to build up a methodological approach. On the one hand, the comparative education approach considers the globalization process as a phenomenon with differences and trends that must be learned through cross-disciplinary research and regarding a set of variables to display the social and historical contexts, economic and social structures, intellectual traditions, and political cultures, among others. This comparison shows the differences between the pathway of the evolutions and goals of the national education systems within globalization dynamics. [26,27]. On the other hand, this research carried out a cross-disciplinary strategy based on science education frameworks [28] and definitions and categories from educational sociology, exploring the curriculum theory allowed to define curriculum policy as an empirical dimension to observe discursive practices $[29,30]$. The discourses expressed within these discursive practices refer to the link between knowledge and social interest materialized in the curriculum goals [31], and the semantics of purposes and objectives where it is possible to observe the local/global articulation and the different arenas and actors involved in the dynamic of the political decisions and functioning of the national education system [32,33].

\subsection{Materials and Data Analysis}

\subsubsection{Materials}

The main materials of this research were (a) the national documents that contain the general curriculum guidelines and the respective documents to design the curricular processes into the natural sciences area, (b) the coding framework for developing the learning practices in science education and the analytical framework of the scientific literacy concept, and (c) studies and data elaborated to evaluate the implementation of educational reform processes in Colombia and Taiwan [34-36].

\subsubsection{Data Analysis and References for the Coding Framework}

The research employed the content analysis method $[37,38]$ to describe Taiwanese and Colombian curriculum characteristics and patterns. The authors established a coding framework that the coding process would be based upon [39]. Three documents were utilized to develop the coding framework. First, the framework for K-12 science education was used as the main component in developing the coding framework. This document provides a set of eight scientific and engineering practices with expected learning performance for students after 12th grade for each practice. Second, Appendix F of the Next Generation 
Science Standards [40] included more detailed learning performance for each grade (from 7th to 9th). Finally, the PISA science framework was used to triangulate with the other two documents. The PISA scientific framework is focused on three scientific competencies that are similar to some of the SEPs mentioned in the first document. The seven overall guiding levels for establishing PISA test items were used in the coding framework as reported earlier.

The authors carefully read the three documents and selected learning performance for each SEP. Since the learning performance in the original documents were written as a mixture of complex clauses built around one or even several verbs, the analysis consisted of associating semantic field, anchoring verb, categories, and SEP. Two final coding frameworks were established. One was a simplified coding framework consisting of sub-practices and descriptions. It was used as the major framework in the coding process. The other was a concrete coding framework with detailed sub-practices and sub-practice indicators. These conceptual instruments were used to analyze the curriculum guideline documents, identifying their convergences, alignments, and differences. The discussion and analyses were based on the cognitive demand construct [41], which was clearly expressed in the Taiwanese documents. The actions of production and thinking defined in the Colombian guidelines were analyzed using Bloom's Taxonomy to align our comparative points and units and identify the different places from the problem-solving approach and cognitive abilities. The guideline analyses also entailed developing an interpretation of the statements adjusted to the national and social contexts; what was required to understand the differences about research, investigation, and inquiry into the schools' context; and the main concepts that the respective academic and pedagogical traditions had defined to organize classroom learning. This discussion was a complement to the coding framework construction because through it, the comparative analysis incorporated a set of sociological, historical, and political characteristics. Thus, the association between practices, learning, and actions enlarged its points of comparison and based-data interpretation, and it was carried out through successive approximations.

The comparative analysis strategy was also guided by the structural analysis of discourse [42] through three stages of coding: (a) parallel structure for observing the differences between concepts, structures, rationale, design criteria, political fundaments, pedagogical approaches, sources and intellectual influences, and values, among other aspects related to epistemological and sociological contexts and issues; (b) hierarchical structure for identifying conceptual differences between main definitions and design criteria of both national education systems, having as references the analytical framework of PISA 2018 and the framework of the learning practices in science education; and (c) cross-structure for synthesizing the analysis through the identification of the concordance and alignment focus, following the categorical concurrence and depth-of-knowledge consistency criteria [43].

Coding allows the theoretical approach to be connected with the educational practices. Coding and comparative analysis are procedures to integrate conceptual analysis, quantitative approaches, qualitative observation, and interpretation. They also work as mapping data that link the research questions, aims, and data characterized by their diversity and decision-making process operation [44]. Therefore, the association between analysis units and practices was based on integrating perspective, comparative analysis, and decision into the concordance analysis. This work was based on Kendall's concordance coefficient $(W)$ and is suitable for interjudge reliability [45]. It is used to verify the consistency of the scores of $\mathrm{N}$ works by multiple raters. Kendall's $W$ test can be interpreted as a "harmony coefficient" that measures raters' consistency. Kendall's $W$ test range is between 0 (disagree) and 1 (completely agree). The higher the $\mathrm{W}$ value, the higher the consistency of the raters. In this study, there were three raters coding the content of curriculum guidelines. Among the 44 test codes (activities) in the curriculum guidelines for Colombia, Kendall's $W^{a}$ value was 0.95 (chi-square value $=125, p<00$ ), and for the 15 test codes (standards) in 
the curriculum guidelines for Taiwan, Kendall's $W^{a}$ value was 0.99 (chi-square value $=42$, $p<00)$.

\section{Results}

\subsection{Categorization Data and Concordance}

The following are the analysis results based on production and thinking (Colombia) and learning performance (Taiwan). The framework coding of science education standards was taken as the main reference to observe their concordance; the "Practice" concept offers indicators and observation statements to analyze the curriculum goals and definitions in a comparative perspective. With this strategy, it was possible to identify that Taiwanese curriculum guidelines focus on the practices presented in Table 4.

Table 4. Main practices in the Taiwanese curriculum guidelines.

\begin{tabular}{|c|c|c|c|}
\hline Position & Practice & Taiwanese Curriculum Guidelines & Reference Framework \\
\hline 1 st & $\begin{array}{l}\text { Planning and carrying } \\
\text { out investigations }\end{array}$ & $\begin{array}{l}\text { Taiwan aims at teaching scientific inquiry, or the } \\
\text { method of discovery, especially focusing on } \\
\text { hands-on experimentation not by rote doing the } \\
\text { procedure but rather by understanding, planning, } \\
\text { and recording observations. }\end{array}$ & $\begin{array}{l}\text { Distinction between variables } \\
\text { Prediction of possible results } \\
\text { Operating with objects, } \\
\text { equipment, and resources. } \\
\text { Collecting data and evidence } \\
\text { Revising experimental design. }\end{array}$ \\
\hline 2nd & $\begin{array}{l}\text { Constructing explanations (for } \\
\text { science) and designing } \\
\text { solutions (for engineering) }\end{array}$ & $\begin{array}{l}\text { This reflects one of the science subject goals: to } \\
\text { construct explanations by connecting theory, data, } \\
\text { and findings. This rationale is reflected from the } \\
\text { beginning of the curriculum guidelines. }\end{array}$ & $\begin{array}{l}\text { Use of evidence, models, and } \\
\text { explanations based on } \\
\text { scientific ideas to discover } \\
\text { unknown knowledge. } \\
\text { Use of scientific ideas to } \\
\text { solve problems. }\end{array}$ \\
\hline $3 r d$ & $\begin{array}{l}\text { Asking questions (for } \\
\text { sciences) and defining } \\
\text { problems (for engineering) }\end{array}$ & $\begin{array}{l}\text { This is related to students' prior knowledge and } \\
\text { observation to define questions and problems } \\
\text { worth investigating with scientific methods. }\end{array}$ & Definition of a research object. \\
\hline 4th & $\begin{array}{l}\text { Obtaining, evaluating, and } \\
\text { communicating information. }\end{array}$ & $\begin{array}{l}\text { Effective communication is also a basis in a science } \\
\text { subject. This practice requires students to offer their } \\
\text { explanations of and opinions on other people's } \\
\text { information or reports. }\end{array}$ & $\begin{array}{l}\text { Use of communicating } \\
\text { scientific information, } \\
\text { research, and outcomes. }\end{array}$ \\
\hline
\end{tabular}

In the case of the Colombian curriculum guidelines, the emphasis is observed in Table 5.

Table 5. Main practices in the Colombian curriculum guidelines.

\begin{tabular}{|c|c|c|c|}
\hline Position & Practice & Colombian Curriculum Guidelines & Reference Framework \\
\hline 1 st & $\begin{array}{l}\text { Constructing explanations (for } \\
\text { science) and designing } \\
\text { solutions (for engineering) }\end{array}$ & $\begin{array}{l}\text { This is related to the formulation of explanations } \\
\text { based on everyday knowledge and scientific } \\
\text { knowledge, recognizing theories, contents, } \\
\text { arguments, and models. Students' actions are } \\
\text { related to social issues and the value of } \\
\text { scientific knowledge. } \\
\text { These explanations focus on handling scientific } \\
\text { knowledge about natural sciences and the } \\
\text { living environment. }\end{array}$ & $\begin{array}{l}\text { Students can construct their } \\
\text { explanations, distinguishing } \\
\text { variables, models, } \\
\text { and representations. } \\
\text { Use of evidence, models, and } \\
\text { scientific ideas. } \\
\text { Obtaining evidence from } \\
\text { different experiments. }\end{array}$ \\
\hline 2nd & $\begin{array}{l}\text { Engaging in argument } \\
\text { from evidence }\end{array}$ & $\begin{array}{l}\text { This considers the differentiation between } \\
\text { description, explanation, and evidence to reflect } \\
\text { social issues that can contribute to scientific } \\
\text { knowledge. This emphasis points to using natural } \\
\text { sciences knowledge to understand and act in the } \\
\text { relationship between science, technology, } \\
\text { and society. }\end{array}$ & $\begin{array}{l}\text { Constructing arguments } \\
\text { supported by evidence. } \\
\text { Distinguishing between } \\
\text { claims, data, and reasons. } \\
\text { Respectfully receiving } \\
\text { critiques from peers. }\end{array}$ \\
\hline
\end{tabular}


Table 5. Cont.

\begin{tabular}{|c|c|c|c|}
\hline Position & Practice & Colombian Curriculum Guidelines & Reference Framework \\
\hline $3 \mathrm{rd}$ & $\begin{array}{l}\text { Obtaining, evaluating, and } \\
\text { communicating information. }\end{array}$ & $\begin{array}{l}\text { This practice is based on being able to communicate } \\
\text { features and findings of inquiry processes using } \\
\text { different resources. This practice also refers to } \\
\text { recognizing points of view, critiques, and } \\
\text { skepticism. This work is based on the information } \\
\text { search to participate in debates. }\end{array}$ & $\begin{array}{l}\text { Discussing the validity of data, } \\
\text { hypotheses, and conclusions. } \\
\text { Gathering information from } \\
\text { multiple sources. }\end{array}$ \\
\hline
\end{tabular}

\subsection{Comparative Analysis}

\subsubsection{Alignment and Similarities}

The analysis shows that although important cultural and political differences exist between Taiwan and Colombia, both countries hold on to the Sustainable Development Goals of the United Nations; they are part of their basic definitions in education's respective public policies. There is a convergence towards the relationship between education, citizenship, social inclusion and integration, democracy, human rights, and environment, among other concepts that highlight the national education system's function to achieve good levels of legitimacy, right guarantees, quality of life, and well-being. These factors make up the larger context to understand the importance of measuring and promoting learning quality because without the improvement of educational system effectiveness, these principles of equity could not be achieved. This framework is also a favorable context to value the importance of scientific work and promote in both countries the relationship between scientific knowledge, social identity, citizenship, and reasoned opinions about social issues.

The practices in science education are aligned around the construction of explanations and the communication of inquiry practices. In the first aspect, a thinking structure is expressed through the relationship between theory, data, and findings (Taiwan) or a comprehensive approach to link scientific knowledge and "lifeworld" (Colombia). In the second aspect, communication is related to constructing an explanation and gathering relevant information to think and judge its reliability and validity. These characteristics reinforce the participation in a learning community by following some aspects of scientific practices and communities. Likewise, both curriculum guidelines present mathematics with a similar connotation: being part of research processes, learning processes, and cognitive demands, and as an instrument or means to identify patterns, express relations between variables, or organize data, but not with a mathematization purpose.

\subsubsection{Differences}

One of the main differences between the curricular guidelines analyzed was the duration of their respective schooling processes. In Taiwan, compulsory education lasts 12 years and in Colombia 10 years. Therefore, two ways to synchronize the educational reform processes with curriculum policies were observed. On the one hand, the Colombian national education system developed a curricular construction through the following sequence: curriculum guidelines by areas (1998), basic standards of competencies (2006), and structuring learning (2015). This trajectory advanced from the epistemological and pedagogical definitions towards the definitions of competencies and their coherence criteria to implement the curriculum policy, and finally, towards teaching routes, knowledge, and abilities to achieve. This progression of the Colombian curriculum policy was coupled with a reform process of the national education system's functional aspects in coordination with the National Plan of Education. From 1994-2016, the main reform topics were access and coverage expansion, decentralization, articulation of implementation levels, monitoring and assessments, accreditation and quality assurance, and teacher training. In this process, the curriculum policy did not receive similar attention. 
On the other hand, in the period from 2000 to 2014, the Taiwanese public policy of education developed a curriculum reform process highly coordinated with the extension of compulsory education from 9 years to 12 years. This reform developed a wide field of research and evaluation to achieve a significant alignment between curriculum, teacher training, international assessments, science education, and expectations. In this level of the curriculum policy, the Taiwanese experience also linked its goals with values and representations of the globalization process and contemporary society.

There was a difference of experiences and policies in curriculum alignment in terms of curriculum design and its programmatic level. Taiwan presented a set of instruments to align its curriculum policy according to different expectations, international assessments, goals, and cognitive interests. This alignment means science education practices delimited their development field between learning stages, learning content, and learning practices, as well as with cross-subjects of scientific knowledge. Unlike this policy scheme, Colombian curriculum guidelines were oriented to linking up principles, consistency criteria, and minimum contents to be achieved in the teaching processes. The scheme to define structuring learnings was composed of statements, evidence, and examples to design the learning process at the school and classroom levels. In addition, in this context, it is relevant to note the differences between rationales and core concepts that define the representation of science education: as a cultural resource that enhance the agency, citizenship, and commitment of people to the environment, or as a representation of scientific knowledge. One of the aspects reflecting this difference was the problem-solving approach, which closely connected with the research and experimental experiences. This approach was the central practice of the Taiwanese curriculum guidelines in natural sciences.

The synthesis of this analysis is presented in Table 6 .

Table 6. Synthesis of comparative analysis.

\begin{tabular}{|c|c|c|}
\hline & Goals & Curriculum \\
\hline Taiwan & $\begin{array}{l}\text { Scientific citizenship } \\
\text { Scientific literacy } \\
\text { Science competency }\end{array}$ & $\begin{array}{l}\text { Skills of scientific inquiry } \\
\text { Cross-domains and thinking ability } \\
\text { Trajectories (learning stage-career) } \\
\text { Communication, participation in } \\
\text { decision-making, and problem-solving of } \\
\text { social issues }\end{array}$ \\
\hline Colombia & $\begin{array}{l}\text { Scientific theories and } \\
\text { practices } \\
\text { Impact of scientific knowledge } \\
\text { Commitments and } \\
\text { environment }\end{array}$ & $\begin{array}{l}\text { Nature of science } \\
\text { Disciplinary-based classification of contents } \\
\text { Cognitive demand expressed as minimal } \\
\text { achievements } \\
\text { Demand of curriculum alignment }\end{array}$ \\
\hline
\end{tabular}

From the "Goals" and "Curriculum" categories, the differences between these curriculum structures are displayed two reading lines. The horizontal line links the set of concepts of educational policy (normative definitions) with curriculum theory concepts (cognitive definitions), making intelligible expectations and curriculum designs (Taiwan), and connects the set of values and principles with cognitive ideas influenced by the requirements related to current participation in the OECD's assessments (Colombia). The vertical line shows the differences between curricular languages. For instance, the Taiwanese documents expressed their goals through concepts that integrate definitions of scientific knowledge, pedagogical purposes, and political conceptions. Meanwhile, the Colombian curriculum guidelines were defined as reformed and updated focus due to the changes related to Colombia's international recognition and national actors' claims. In addition, there are distinctions between a curricular language that considers the alignment criteria between knowledge, performance, expectations, and the national education system (Taiwan) and a type of curriculum policy construction that must deal with several pressures 
to harmonize its decentralization policy and its requirements to improve its effectiveness and performance.

\section{Discussion}

The comparative analysis of the curriculum guidelines in natural sciences is based on the encounter between Taiwan and Colombia in the OECD, allowing us to ask about similarities between two systems and sets of education policies that belong to the same knowledge area, political space, and international assessment. The common membership is also a platform to think about academic cooperation scenarios related to science education, quality education goals, and sustainable development. This comparative analysis aims at indicating two key dimensions to activate other research and collaborations and foster the relationship between goals and curriculum components.

The first dimension corresponds to the economic background criterion, which influences the operating conditions of educational institutions. The COVID-19 outbreak has increased the national education system's stress to generate inclusion and social cohesion within the current context. The Colombian situation shows a deepening of gaps since social distancing measures demand an intensive use of technology to continue the educational processes, which cannot be accessed by a significant number of students and teachers $[46,47]$. The current deepening of the gaps are added to the previous asymmetries between Taiwan and Colombia produced in the globalization process. Thus, at least two comparative questions could be posed: Should Colombia and Taiwan be considered two marketization processes of education policies [48]? What are the main differences between a marketization process through a national education policy [49] and another policy based on educational services offered in a regulated space by the State and additional corporative agreements [50]?

The results of this comparative analysis are also in connection with sustainability factors. On the one hand, in 2016, Colombia started a political change process strongly defined by the Peace Agreement signed after 60 years of armed conflict. In this new context, the public policy of education has received again the responsibility to build up the cultural process required to enhance democracy and reconciliation. [51] Curriculum goals should promote the development, among other references, of the OECD's aims, that is, a connection between educational processes, learning, and social issues, including regional development, environment protection, and the transformation process of the education system following the digital economy criteria. [52] In the same context, the Ten-Year National Education Plan 2016-2026 defined as its main task the regulation and delimitation of the right to education according to different UNESCO conferences and Sustainable Development Goals and the materialization of quality lifelong learning for everyone. [53] On the other hand, Taiwanese diplomatic strategies to enlarge its international recognition have tended to combine the economic factor with assistance initiatives that have increased its importance in the current context. [54] In addition to its manufacturing capabilities, democratic practices, and health strategies to prevent the spread of COVID-19, Taiwan can also develop integration through educational collaboration, sharing its successful experiences of effectiveness in schools and student performance. Both countries have different development rhythms and strategies, but both face the challenge of adapting their public policies to sustainability assessment procedures and indicators. [55,56] In the educational field, this aspect refers to developing cooperation processes to improve public education, pointing at the implementation process of linking science, education, teacher training, technological innovation, and curriculum policies. Educational institutions and organizations are required to deploy competencies to adapt and realign their performances in new environments related to quality and accountability assurance systems [57] and to responses to natural disasters that disrupt face-to-face educational processes [58].

The second dimension includes the analysis of the reform processes presented in the Colombian and Taiwanese contexts. In this comparative analysis phase, it is possible to indicate two beginning lines of reflection: (a) For its membership in the OECD, Colombia re- 
ceived a set of suggestions to improve all the elements from the national education systems, such as budget, management, responsibility, fiscal structure, regional governments, schools, and educational agents. The educational policy that promotes curricular autonomy and teachers' decisions about school life is a critical point because the material, cognitive, and cultural conditions have not been developed yet. In this sense, the schools' representation as professional communities based on knowledge will continue being a conflict scenario around the pedagogical practice, initial teaching training, and teachers' political place in constructing a society model [59]. In Colombia, there is a lower level of communication between agents in the scientific and educational fields. Colombian public policy in science was created in 2020, following an agenda of internal consolidation that is expected to be reached in 2034. (b) Taiwanese reform process could be placed into a meta-level of evaluation, given that several policies and programs are observing phenomena arising after the second generation of curricular reform. For instance, this is expressed in research on the impact of international assessment on developing scientific competencies or the Taiwanese strategy to encourage synergy between higher education, science, research, and innovation [60]. Additionally, Taiwanese projects to develop cooperation around Science, Technology, Engineering, Mathematics (STEM) education stand out as an initiative to expand an international knowledge space, following the guidelines of public policies and international strategy to cooperate into a global ord. From experiences such as this, it is possible to cooperate with Colombian reflections and perspectives on knowledge-based educational change.

Despite their different pathways and development stages, Taiwan and Colombia can implement cooperation processes and move towards quality education practices. For example, both countries could share experiences and learn how to synchronize curriculum innovation with the national education system's reform process. However, there are also important dialogue and collaboration topics at the programmatic level, such as how to align curriculum guidelines with knowledge-based curriculum standards to improve students abilities, how to develop initiatives of cooperation into international knowledge spaces such STEM education, and what the key factors to foster the technological, pedagogical, content knowledge of teachers' performance are. These three questions converge towards the teacher training field and highlight universities' importance to achieve a sustainable change and innovation process.

\section{Conclusions and Implications}

This comparative analysis delimited a framework to tackle the component of practices and performances in curriculum guidelines for natural sciences from Taiwan and Colombia. A coding and conceptual analysis were developed, working over a set of curriculum policy documents for comparison. The framework of science education practices was the reference to analyze production and thinking and learning practices, and to define their concordance and alignment. Taiwanese curriculum guidelines have as their core practice the development of inquiries, research, and experimentations to promote scientific literacy and citizenship, whereas Colombia has as a central practice the construction of explanations based on scientific ideas, gathering information, and using evidence. There is also a concordance over practices related to obtaining and communicating information. These results show the importance of curriculum policies such as epistemological definitions, diagnosing and representing social expectations, and the alignment of instruments, curriculum definitions, and design criteria of teaching processes. The differences between these factors' behaviors into national curriculum policies should be considered part of a comparative strategy of contexts, medium-term processes to reform the national education systems or schooling features and curriculum guidelines from their intellectual traditions, theoretical, and pedagogical influences, and current requirements of policies.

This research was developed as a comparative analysis between Taiwan and Colombia curriculum guidelines since there are no previous similar studies. However, public policies in education are useful for starting and drawing research lines and case studies. This 
characteristic was a limitation to increase the control of variables, analysis units, and coding of qualitative data; in another sense, this limitation should be complemented with more complex analyses. From the curriculum perspective, this work was limited to observing the convergences and differences between national curriculum guidelines and the natural sciences field. Although this limitation contributed to the analysis' reliability, it should be integrated into the analysis related to variables such as technology, knowledge, teacher education, and networks, among others. It should also be considered as another knowledge area.

According to the comparative perspective, the future scenarios to develop more research about the public policies of education from Taiwan and Colombia depend on at least three factors: (a) the progression of the diplomatic and international integration between these two countries and the capabilities to project their OECD membership towards more collaboration. The alignment between the national curriculum guidelines and the Sustainable Development Goals is a strategic scenario and subject to generate reflection lines about pertinence, adaptation, and feasibility of comparative and collaborative research and communicate the academic and university interests with decision-makers' spaces for longterm strategic reflections. The remaining two factors are (b) the dynamic of the constitution and development of the international knowledge spaces, and the cooperation that both countries agree to implement through university collaboration, curriculum investigation, international assessments, cross-disciplinary curriculum design, teachers' education, and technological and pedagogical practices, among other topics, and (c) the construction of a platform for communication among researchers, academic communities, and academic programs to develop a suitable comparative analysis of resources, capabilities, traditions, frameworks, policies, gaps, and social indicators, among other contents. These indicators' pertinence would depend on the specific ways to agree with research teams, institutions, educational actors, and policy-makers.

To develop future research, one aims to identify topics to implement cooperation practices between researchers and universities within the educational field and curriculum policies. The current context marked by the COVID-19 outbreak also requires increasing the resources and solutions to protect and continue with the learning processes and the link between teachers, students, and learning practices. These aspects highlight research lines such as technological pedagogical content knowledge (TPCK), STEM education and teacher education, and online learning. Different cases studies are possible to consider as future research topics: (a) analysis of curricular alignment strategies in Taiwan and their impact on international assessments' performance. This subject could produce knowledge to transfer different learnings and suggestions to develop in Colombia. The other two include (b) teacher education, research profiles, and cross-disciplinary concepts to define curriculum features into specific knowledge areas and (c) characterizing reform processes in the Taiwanese and Colombian national education systems.

In the theoretical dimension, this research's main implications are related to following the current curriculum reflections from their definition as public policy. This shift has a significant impact on the curriculum's pedagogical and political dimensions because it requires communicating different theoretical frameworks through their concepts, institutional definitions, and architectures. Moreover, this curriculum conception promotes an analysis of curriculum policies linking the classroom processes with goals, research programs, decision-making processes, and a metacognition level. This conceptual shift also implies a dialogue between theoretical, pedagogical, and intellectual traditions to understand the rationales, concepts, and approaches on which the respective curriculum policies are based. In the practical dimension, this work highlights the importance of connecting the academic collaboration initiative with decision-making processes and policy-makers to encourage the construction of alliances between universities, doctoral programs, researchers and research teams, and students, among other actors. Universities have an opportunity to open a space of cooperation with impact face to the challenges of the current world and its changes. 
Author Contributions: Methodology, P.-H.C., N.V.H., and J.M.; validation, P.-H.C., N.V.H., and J.M.; formal analysis, P.-H.C., N.V.H., and J.M.; resources, C.-Y.C.; data curation, N.V.H. and J.M.; writing-original draft preparation, J.M.; supervision, C.-Y.C.; project administration C.-Y.C.; funding acquisition, C.-Y.C. All authors have read and agreed to the published version of the manuscript.

Funding: This work was financially supported by the National Science Council of Taiwan under contracts the MOST 107-2634-F-008-003 and the "Institute for Research Excellence in Learning Sciences" of National Taiwan Normal University (NTNU) from the Featured Areas Research Center Program within the framework of the Higher Education Sprout Project by the Ministry of Education (MOE) in Taiwan.

Institutional Review Board Statement: Not applicable.

Informed Consent Statement: Not applicable.

Data Availability Statement: Data sharing is not applicable to this article.

Acknowledgments: The authors would like to express their gratefulness to Terrence from the Science Education Center, who helped in the English editing process. We also express our gratitude to Sally Chien from the Science Education Center (NTNU) and Camila Estrada from the Universidad Autónoma de Colombia, who collaborated in the validation, analysis, and writing-original draft preparation.

Conflicts of Interest: The authors declare no conflict of interest. The founding sponsors had no role in the study's design, in the collection, analyses, or interpretation of data, in the writing of the manuscript, and in the decision to publish results.

\section{References}

1. National Research Council. A Framework for K-12 Science Education: Practices, Crosscutting Concepts, and Core Ideas; The National Academy Press: Washington, DC, USA, 2012.

2. OECD. PISA 2018 Assessment and Analytical Framework; OECD Publishing: Paris, France, 2019.

3. Wahlström, N. When transnational curriculum policy reaches classrooms-teaching as directed exploration. J. Curric. Stud. 2018, 50, 654-668. [CrossRef]

4. Webb, N. Criteria for Alignment of Expectations and Assessments in Mathematics and Science Education; National Science FoundationUniversity Wisconsin-Madison: Washington, DC, USA, 1997.

5. Moore, R.; Young, M. Knowledge and the Curriculum in the Sociology of Education: Towards a reconceptualization. Br. J. Sociol. Educ. 2001, 22, 445-461. [CrossRef]

6. Chang, C. Taiwanese science and life technology curriculum standards and earth systems education. Int. J. Sci. Educ. 2005, 27, 625-638. [CrossRef]

7. Khuyen, N.T.T.; Van Bien, N.; Lin, P.-L.; Lin, J.; Chang, C.-Y. Measuring Teachers' Perceptions to Sustain STEM Education Development. Sustainability 2020, 12, 1531. [CrossRef]

8. Burden, K.; Aubusson, P.; Brindley, S.; Schuck, S. Changing knowledge, changing technology: Implications for teacher education futures. J. Educ. Teach. 2015, 42, 4-16. [CrossRef]

9. Osborne, J.F. Not "hands on" but "minds on": A response to Furtak and Penuel. Sci. Educ. 2019, 103, 1280-1283. [CrossRef]

10. Ford, M.J.; Forman, E.A. Chapter 1: Redefining Disciplinary Learning in Classroom Contexts. Rev. Res. Educ. 2006, 30, 1-32. [CrossRef]

11. Duschl, R.A.; E Grandy, R. Two Views about Explicitly Teaching Nature of Science. Sci. Educ. 2013, 22, 2109-2139. [CrossRef]

12. National Research Council. Next Generation Science Standards: For States, by States; The National Academies Press: Washington, DC, USA, 2013.

13. Lertdechapat, K.; Faikhamta, C. Science and engineering practices in a revised Thai science curriculum. In Proceedings of the 6th International Conference for Science Educators and Teachers, Bangkok, Thailand, 5-7 April 2018.

14. Holbrook, J.; Rannikmae, M. The meaning of scientific literacy. Int. J. Environ. Sci. Educ. 2009, 4, $275-288$.

15. Norris, S.P.; Phillips, L.M. How literacy in its fundamental sense is central to scientific literacy. Sci. Educ. 2003, 87, 224-240. [CrossRef]

16. OECD. PISA 2018 Assessment and Analytical Framework; OECD Publishing: Paris, France, 2018.

17. OECD. PISA 2015 Results (Volume I): Excellence and Equity in Education; OECD Publishing: Paris, France, 2016.

18. OECD. How PISA Results Are Reported: What Is a PISA Score? OECD Publishing: Paris, France, 2019.

19. Sothayapetch, P.; Lavonen, J.; Juuti, K. A comparative analysis of PISA scientific literacy framework in Finnish and Thai science curricula. Sci. Educ. Int. 2013, 24, 78-97.

20. República de Colombia, Ministerio de Educación Nacional. Lineamientos Curriculares Ciencias Naturales y Educación Ambiental. 1998. Available online: https://www.mineducacion.gov.co/1621/articles-89869_archivo_pdf5.pdf (accessed on 27 October 2020). 
21. República de Colombia, Ministerio de Educación Nacional. Estándares Básicos de Competencias en Lenguaje, Matemáticas, Ciencias y Ciudadanas; Ministerio de Educación Nacional: Bogotá, Colombia, 2006.

22. Republic of China, Ministry of Education. Curriculum Guidelines of 12-Year Basic Education Natural Sciences; unpublished.

23. Schriewer, J. L'internationalisation des discours sur l'éducation: Adoption d'une « idéologie mondiale » ou persistance du style de « réflexion systémique » spécifiquement nationale. Rev. Française Pédagogie 2004, 146, 7-26. [CrossRef]

24. Kazamias, A.M. Comparative Education: Historical Reflections. In International Handbook of Comparative Education; Springer Netherlands: Heidelberg, Germany, 2009; pp. 139-157.

25. Fairclough, N. Analysing Discourse: Textual Analysis for Social Research; Tylor and Francis e-Lybrary: Oxfordshire, UK, 2004.

26. Wahlström, N.; Sundberg, D. Discursive institutionalism: Towards a framework for analysing the relation between policy and curriculum. J. Educ. Policy 2017, 33, 163-183. [CrossRef]

27. Popkewitz, T.S. Curriculum study, curriculum history, and curriculum theory: The reason of reason. J. Curric. Stud. 2009, 41, 301-319. [CrossRef]

28. Wahlström, N. Where is 'the political' in curriculum research? J. Curric. Stud. 2018, 50, 711-723. [CrossRef]

29. Rosemund, M. The current discourse on curriculum change: A comparative analysis of national reports on education. School knowledge in comparative and historical perspective. In Changing Curricula in Primary and Secondary Education; Benavot, A., Braslavsky, C., Eds.; Springer: Hong Kong, China, 2007; pp. 173-194.

30. Arias, D.; Díaz, O.; Garzón, I.; León, A.; Rodríguez, S.; Valbuena, E. Entre las Exigencias de Calidad y las Condiciones de Desigualdad: Formación Inicial de Profesores en Colombia; Colciencias-Universidad Pedagógica Nacional: Bogotá, Colombia, 2018.

31. Montero, M.S. Escuela pública colombiana: Entre la función social y la tecnología. In Educación y Pedagogía. Pasajes, Encuentros, Conversaciones; Montero, M.S., Páez, E., Eds.; UPTC: Tunja, Colombia, 2015.

32. Chen, H.L.; Huang, H.Y. Advancing 21st Century Competencies in Taiwan; Asia Society: Taipei, Taiwan, 2017.

33. Cohen, L.; Manion, L.; Morrison, K. Research Methods in Education; Routledge: London, UK, 2011.

34. Krippendorff, K. Content Analysis: An Introduction to Its Methodology; Sage Publications: Los Angeles, CA, USA, 2018.

35. Bernard, H.R.; Ryan, G. Text analysis. In Handbook of Methods in Cultural Anthropology; AltaMira Press: Walnut Creek, CA, USA, 1998.

36. National Research Council. Next Generation Science Standards; National Academies Press: Washington, DC, USA, 2013.

37. Tsaparlis, G. Cognitive Demand. In Encyclopedia of Science Education; 2015. Available online: https://link.springer.com/ referenceworkentry/10.1007\%2F978-94-007-2150-0_40 (accessed on 24 November 2020).

38. Martinic, S. El estudio de las representaciones y el Análisis Estructural del Discurso. In Metodologías de Investigación Social. Introducción a los Oficios, 1st ed.; Cerón, M.C., Ed.; LOM Ediciones: Santiago, Chile, 2006; pp. 299-325.

39. Webb, N. An Analysis of the Alignment between Mathematics Standards and Assessments for Three States; Center for Education Research: Madison, WI, USA, 2003.

40. Elliot, V. Thinking about the Coding Process in Qualitative Data Analysis. Qual. Rep. 2018, 23, $2850-2861$.

41. Habibi, A.; Sarafrazi, A.; Izadyar, S. Delphi Technique Theoretical Framework in Qualitative Research. IJES 2014, 3, 8-13.

42. CEPAL. Las Oportunidades de la Digitalización en América Latina Frente al Covid-19. Available online: https://repositorio. cepal.org/bitstream/handle/11362/45360/4/OportDigitalizaCovid-19_es.pdf (accessed on 6 April 2020).

43. Molina, J. Conjurar la crisis: La respuesta gubernamental a la epidemia del COVID-19 en Colombia (marzo-julio 2020). Q. Lat. Am. Econ. Trade 2020, 42, 25-42.

44. Bouvier, A.; Gauthier, R.; Sanselme, M. Au miroir de l'Asie: Questions d'éducation comparée. Introduction. Rev. Int. Éducation Sèvres 2015, 68, 29-35. [CrossRef]

45. Chang, D.-F.; Wu, C.-T.; Ching, G.; Tang, C.-W.; Xiao, L. Globalization and Higher Education in Taiwan. In New Knowledge in a New Era of Globalization; Pachura, P., Ed.; Intech: Rijeka, Croatia, 2011.

46. Páez, E. La Organización Mundial del Comercio, los Educational Services y la Universidad. Políticas Públicas, Calidad, Servicios Educacionales y Universidad en Colombia; Universidad Pedagógica y Tecnológica de Colombia: Tunja, Colombia, 2020.

47. Rodríguez, S. Lecciones históricas para pensar una cátedra de la paz. In Bitácora para la Cátedra de la Paz. Formación de Maestros y Educadores para una Colombia en Paz; Ortega, P., Ed.; Universidad Pedagógica Nacional: Bogotá, Colombia, 2016 ; pp. 135-158.

48. OECD. OECD Reviews of Digital Transformation: Going Digital in Colombia; OECD Publishing: Paris, France, 2019.

49. República de Colombia, Ministerio de Educación Nacional. Plan Nacional Decenal de Educación 2016-2026. El Camino Hacia la Calidad y la Equidad; Ministerio de Educación: Bogotá, Colombia, 2017.

50. Portada, R.A.; Lem, S.B.; Paudel, U. The Final Frontier: China, Taiwan, and the United States in Strategic Competition for Central America. J. Chin. Politi. Sci. 2020, 25, 551-573. [CrossRef] [PubMed]

51. Popescu, C.R.G. Sustainability Assessment: Does the OECD/G20 Inclusive Framework for BEPS (Base Erosion and Profit Shifting Project) Put an End to Disputes Over The Recognition and Measurement of Intellectual Capital? Sustainability 2020, 12, 4. [CrossRef]

52. Streimikiene, D.; Mikalauskiene, A.; Kiausiene, I. The Impact of Value Created by Culture on Approaching the Sustainable Development Goals: Case of the Baltic States. Sustainability 2019, 11, 6437. [CrossRef]

53. Lemaitre, M. Quality Assurance in Higher Education, a Global Perspective. In Encyclopedia of International Higher Education Systems and Institution; 2017. Available online: https://link.springer.com/referenceworkentry/10.1007\%2F978-94-017-9553-1_263-1 (accessed on 30 October 2020). 
54. Dhawan, S. Online Learning: A Panacea in the Time of COVID-19 Crisis. J. Educ. Technol. 2020, 49, 5-22. [CrossRef]

55. Radinger, T.; Echazarra, A.; Guerrero, G.; Valenzuela, J.P. OECD Reviews of School Resources: Colombia 2018; OECD Publishing: Paris, France, 2018.

56. Kuo, Y.C.; Chan, S.J. Research, Development and Innovation: Transformation in Taiwanese Higher Education. In Transformations in Higher Education Governance in Asia. Policy, Politics and Progress; Jarvis, D., Mok, K.H., Eds.; Springer: Hong Kong, China, 2019; pp. 171-196.

57. Chang, C.Y.; Lin, P.L. One STEM teacher, one thousand STEM mind (talents)-The aim of e-Learning Integrated STEM Education Center (eLISE). Rev. Hist. Edu. Latinoam. under review.

58. Soto, D.; Mesa, F.; Caro, E. Convergencia digital en la Universidad Colombiana del siglo XX al XXI. Rev. Hist. Edu. Latinoam. 2012, 14, 265-300. [CrossRef]

59. Wahono, B.; Chang, C.-Y. Assessing Teacher's Attitude, Knowledge, and Application (AKA) on STEM: An Effort to Foster the Sustainable Development of STEM Education. Sustainability 2019, 11, 950. [CrossRef]

60. Palvia, S.; Aeron, P.; Gupta, P.; Mahapatra, D.; Parida, R.; Rosner, R.; Sindhi, S. Online Education: Worldwide Status, Challenges, Trends, and Implications. J. Glob. Inf. Technol. Manag. 2018, 21, 233-241. [CrossRef] 